\title{
Cadmium chloride enhances cisplatin sensitivity in osteosarcoma cells by reducing FOXM1 expression
}

\author{
KONGHE HU ${ }^{1}$, WENQUAN XIE ${ }^{1}$, SONGJIA NI ${ }^{2}$, SHUMIN YAN ${ }^{1}$, \\ GAOQIANG TIAN $^{1}$, WEIZHONG QI $^{2}$ and YANG DUAN ${ }^{2}$ \\ ${ }^{1}$ Department of Spine Surgery, The Affiliated Yuebei People's Hospital of Shantou University Medical College, \\ Shaoguan, Guangdong 512025; ${ }^{2}$ Department of Orthopedics, Zhujiang Hospital, Southern Medical University, \\ Guangzhou, Guangdong 510280, P.R. China
}

Received November 9, 2019; Accepted April 2, 2020

DOI: $10.3892 /$ or.2020.7632

\begin{abstract}
Osteosarcoma is a highly malignant disease and is associated with a poor patient prognosis and a high mortality rate. Disease prognosis significantly correlates with chemotherapeutic responses. Cadmium is a heavy metal with specific effects on bone, but its benefits for osteosarcoma treatment have not been characterized. In the present study, cadmium chloride was used to treat MG63 osteosarcoma cells, and their gene expression profiles were assessed by GeneChip technology. We found that forkhead box protein M1 (FOXM1) was downregulated by cadmium chloride, and lentiviral-mediated silencing of FOXM1 confirmed a role for this factor in the cisplatin resistance of MG63 cells. In nude mice, cadmium chloride enhanced the sensitivity of osteosarcoma to cisplatin, an effect mediated by FOXM1. Collectively, these data indicate that cadmium chloride can alter the sensitivity of osteosarcoma cells to cisplatin through FOXM1, highlighting it as a potential therapeutic target and prognostic factor for osteosarcoma.
\end{abstract}

\section{Introduction}

Osteosarcoma (OS) is a common primary malignant tumor, that accounts for 1 out of 5 of all diagnosed primary malignant tumors. Children and adolescents are high-risk OS

Correspondence to: Dr Weizhong Qi or Dr Yang Duan, Department of Orthopedics, Zhujiang Hospital, Southern Medical University, Guangzhou, Guangdong 510280, P.R. China

E-mail: qwz90315@163.com

E-mail: duanyang2011@163.com

Abbreviations: $\mathrm{CdCl}_{2}$, cadmium chloride; $\mathrm{DAB}$, diaminobenzidine; DMEM, Dulbecco's modified Eagle's medium; DMSO, dimethyl sulfoxide; FBS, fetal bovine serum; FOXM1, forkhead box protein M1; GAPDH, glyceraldehyde-3-phosphate dehydrogenase; OS, osteosarcoma; RT-qPCR, quantitative real-time polymerase chain reaction; TUNEL, terminal deoxynucleotidyl transferase-mediated dUTP-biotin nick end labeling

Key words: osteosarcoma, cisplatin, cadmium chloride, forkhead box protein M1, drug sensitivity populations (1). OS originates from primitive mesenchymal bone cells and often occurs in long bones, such as the proximal humerus and distal femur (2). For the past 20 years, epidemiological studies report that the global annual incidence of OS is $\sim 3$ million, with a male to female incidence ratio of 5:1, and OS is notorious for its high degree of malignancy, rapid proliferation, high recurrence rate and low long-term survival rates (3). Current treatments have evolved from traditional amputation surgery to local radiotherapy and adjuvant chemotherapy (4). Although the cure rate of OS has increased, due to its high degree of malignancy and metastasis, recurrence and low 5-year survival rates $(\leq 20 \%)$ persist $(5,6)$.

Clinically, OS patients show multiple metastases in the body. Although treatment with neoadjuvant chemotherapy combined with surgery improves the survival rates of OS patients, hearing impairment, liver and kidney damage, and hematopoietic dysfunction frequently occur (7). Cadmium is a common industrial heavy metal that is widely used in manufacturing. Cadmium has toxic effects on various organs and systems, causing bone damage, osteoporosis and osteomalacia $(8,9)$. Since Coogan and colleagues reported the antitumor effects of cadmium, it has become the focus of intensive research efforts (10). Studies have shown that cadmium inhibits cell proliferation and induces DNA damage and apoptosis (11). Toxicology studies show that bone is its major site of accumulation in the human body and represents the main target organ (12).

In the present study, we explored the potential of cadmium chloride to reduce the proliferation, migration and apoptosis of OS cells. Using gene chip technology and in vivo and in vitro assessments, cadmium chloride was found to reduce the growth of OS cells and enhance their sensitivity to cisplatin (DDP) through the regulation of forkhead box protein M1 (FOXM1). Cadmium chloride was also found to enhance cisplatin sensitivity in OS nude-mouse models.

\section{Materials and methods}

Reagents and antibodies. Cadmium chloride $(\mathrm{CdCl} 2)$, Cisplatin (DDP), and 2,7-dichlorofluorescin diacetate were obtained from Sigma-Aldrich/Merck KGaA. Dulbecco's 
modified Eagle's medium (DMEM) with high glucose, penicillin, streptomycin and fetal bovine serum (FBS) were obtained from Thermo Fisher Scientific, Inc. The MTT Cell Proliferation and Cytotoxicity Assay Kit was purchased from Beyotime Institute of Biotechnology. The following antibodies were used: Cleaved caspase-3 antibody [dilution, 1:1,000 for Western blot analysis (WB); cat. \#9664; Cell Signaling Technology, Inc. USA (CST)], Bcl-2 (dilution 1:1,000 for WB; cat. \#15071; CST), BAX (dilution 1:1,000 for WB; cat. \#5023; CST), MMP-2 (dilution 1:1,000 for WB; cat. \#4022; CST), MMP-9 (dilution 1:1,000 for WB; cat.\#3852; CST), E-cadherin (dilution 1:2,000 for WB; cat. \#3195; CST), FOXM1 (dilution 1:80 for IHC, 1:1,000 for WB; cat. no. ab232649; Abcam) and glyceraldehyde-3-phosphate dehydrogenase (GAPDH) (dilution 1:1,000 for WB).

Tumor cell lines and culture. The human embryo immortalized osteoblast cell line Hfob1.19 and OS cell lines MG63, U2OS, 143B and SaoS2 were purchased from Yong Jin Biotech and cultured in DMEM containing 10\% FBS, penicillin $100 \mathrm{U} / \mathrm{ml}$ and streptomycin $100 \mathrm{pg} / \mathrm{ml}$, in $5 \% \mathrm{CO}_{2}$ at $37^{\circ} \mathrm{C}$. Cells were assessed when in the logarithmic growth phase.

Projection electron microscopy. Cells in the logarithmic growth phase were plated into 6-well plates at a density of $5 \times 10^{5}$ cells/well. After incubation for $12-24 \mathrm{~h}$, the cells were treated with $20 \mu \mathrm{M}$ cadmium chloride $\left(\mathrm{CdCl}_{2}\right)$ for $24 \mathrm{~h}$ and fixed in $2.5 \%$ glutaraldehyde solution overnight at $4^{\circ} \mathrm{C}$. The cells were washed in PBS, fixed in $1 \%$ citric acid for $1-2 \mathrm{~h}$, and dehydrated with ethanol. Cells were mounted using embedding agent, and the ultrastructural changes of the cells were observed under an electron microscope (magnification, x1,000 and $\times 5,000)$.

Drug toxicity. Cells $\left(1 \times 10^{5}\right.$ cells/ml) were seeded in 96-well plates at $200 \mu \mathrm{l}$ per well. After the cells had grown to a confluent state, the culture medium was discarded and $200 \mu \mathrm{l}$ of serum-free medium containing different final concentrations of $\mathrm{CdCl}_{2}(0,10,20,30,40,50 \mu \mathrm{M})$ or DDP $(0,5,10$, $15,20,25 \mu \mathrm{M})$ was added to each well. Three replicates were plated for each group. After $24 \mathrm{~h}$ of incubation at room temperature (RT), the culture medium was discarded. Then, $200 \mu \mathrm{l}$ thiazole blue $(0.5 \mathrm{mg} / \mathrm{ml})$ was added to each well. After incubation for $4 \mathrm{~h}$ at RT, the waste solution was discarded and dimethyl sulfoxide ( $150 \mu \mathrm{l} /$ well) was added and mixed thoroughly for $10 \mathrm{~min}$; the absorbance A (wavelength: $570 \mathrm{~nm}$ ) of each well was detected with a microplate reader. The cell inhibition rate and half maximal inhibitory concentration $\left(\mathrm{IC}_{50}\right)$ were calculated.

Cell proliferation. Cells were seeded into 96-well plates at $1 \times 10^{5}$ cells per well, and cultured for $24 \mathrm{~h}$ at RT. Different concentrations of $\mathrm{CdCl}_{2}$ were then added to the culture medium for different times. Control groups were treated with an equal volume of dimethyl sulfoxide (DMSO). MTT reagent (20 $\mu \mathrm{l})$ was added to each well, and supernatants were discarded after $4 \mathrm{~h}$. DMSO $(150 \mu \mathrm{l})$ was added to each well to dissolve the MTT reagent and absorbances were measured at $490 \mathrm{~nm}$. Inhibition rate formula: Inhibition rate $(\%)=($ Control group value-Treatment group value)/Control group value $\times 100 \%$.
Transwell assay. A total of $1 \times 10^{6}$ cells in serum-free medium were seeded into the upper chamber, while the lower chamber was maintained in $10 \%$ FBS medium. After incubation for $24 \mathrm{~h}$ at RT, migratory cells at the bottom of the upper chamber were fixed with $4 \%$ paraformaldehyde for $30 \mathrm{~min}$, stained with $0.5 \%$ crystal violet for $15 \mathrm{~min}$ and then counted under an inverted microscope (magnification, $\mathrm{x} 400$ ). Data were analyzed using ImageJ V1.8.0 software (National Institutes of Health).

Lentivirus infection. Human FOXM1-specific silenced and overexpressing lentivirus and corresponding negative control lentivirus were purchased from Genechem. The sh-FOXM1 group was transfected with the specific silenced sequence, the FOXM1 group was transfected with the specific overexpressing sequence. The sh-NC and the vector group were transfected with corresponding negative control lentivirus. MG63 cells were seeded into 6-well plates and transfected with the indicated lentiviruses, and the multiplicity of infection (MOI) was 20. At $\sim 30 \%$ confluency, the cells were infected for $10 \mathrm{~h}$ and the culture media was replaced. Fluorescence intensities were measured at $72 \mathrm{~h}$ post infection to confirm lentivirus transduction, which reached an efficiency of $\sim 70-80 \%$. Forty-eight hours after observing fluorescence, cells were collected and used for follow-up studies.

Apoptosis and cell counting. Adherent MG63 cells were fixed in $4 \%$ paraformaldehyde at $4^{\circ} \mathrm{C}$ for $15 \mathrm{~min}$. Cells were treated with $0.1 \%$ Triton-X for $10 \mathrm{~min}$ and terminal deoxynucleotidyl transferase-mediated dUTP-biotin nick end labeling (TUNEL) was performed for $1 \mathrm{~h}$ at $37^{\circ} \mathrm{C}$ to allow diaminobenzidine (DAB) development. Imaged sections showing brown granules in the nucleus were deemed TUNEL-positive cells. Five fields (x400) were selected for each slice and the nucleus and TUNEL-positive cells were then observed under a fluorescence microscope (Nikon), and the apoptosis rate (TUNEL-positive cells/nucleus) of five random fields were calculated.

Immunohistochemical staining. For immunohistochemical analysis, mouse cancer tissues were fixed in $10 \%$ formalin at RT for $24 \mathrm{~h}$ and paraffin-embedded. Sections (5- $\mu \mathrm{m}$ thick) were dewaxed and dehydrated in a gradient ethanol series. Endogenous peroxidase activity was quenched by incubating sections in methanol containing $3 \% \mathrm{H}_{2} \mathrm{O}_{2}$ for $10 \mathrm{~min}$ and heating sections in decanoic acid at $65^{\circ} \mathrm{C}$ for $10 \mathrm{~h}$ for antigen retrieval. Paraffin sections were added with anti-human FOXM1, followed by incubation overnight at $4^{\circ} \mathrm{C}$. Then the sections were reacted with goat anti-rabbit $\lg \mathrm{G}-\mathrm{HRP}$ polymer (Beyotime Institute of Biotechnology) at $37^{\circ} \mathrm{C}$ for $20 \mathrm{~min}$, followed by color exposure using DAB.

Western blot analysis. Total proteins were extracted from the tissues or cells. Protein concentrations were measured via bicinchoninic acid assays (Nanjing Keygen Biotechnology Co., Ltd.). Protein samples $(50 \mu \mathrm{g})$ were separated on $10 \%$ polyacrylamide gels and transferred to Hybond ${ }^{\circledR}$ polyvinylidene difluoride membranes (Millipore). Membranes were blocked in 5\% fat-free milk for $2 \mathrm{~h}$ at room temperature and probed with primary antibodies (cleaved caspase-3, Bcl-2, Bax, MMP-2, MMP-9, E-cadherin, FOXM1 and GAPDH) 
overnight at $4^{\circ} \mathrm{C}$. Membranes were labeled with the appropriate secondary antibody for $2 \mathrm{~h}$, and protein bands were visualized using electrochemiluminescence hypersensitive luminescent solution. Data were analyzed using ImageJ software (V1.8.0; National Institutes of Health).

Quantitative real-time polymerase chain reaction ( $R T$ - $q P C R)$ analysis. Cells or tissues were lysed in TRIzol reagent (Sigma-Aldrich/Merck KGaA) and air dried following the addition of chloroform, isopropanol, and ethanol. FOXM1 primers were: 5'-GGAGGAAATGCCACACTTAGCG-3' and 5'-TAGGACTTCTTGGGTCTTGGGGTG-3. Samples were reverse transcribed into cDNA and RT-qPCR was performed using reverse transcription reagent on a LightCycler 96 (Roche Life Sciences) using Real-Time PCR Mix (Vazyme Biotech Co. Ltd.). The reaction conditions were: $95^{\circ} \mathrm{C}$ pre-heated for $3 \mathrm{~min}, 95^{\circ} \mathrm{C}$ denaturation for $30 \mathrm{sec}, 60^{\circ} \mathrm{C}$ annealing for $30 \mathrm{sec}$ and involving 40 cycles. Gene expression was assessed using the $2^{-\Delta \Delta \mathrm{Cq}}$ method relative to GAPDH expression (13). Two independent experiments were performed in triplicate for each RT-qPCR.

RNA sequencing and functional enrichment analysis. Total RNA was isolated from MG63 cells using TRIzol (Invitrogen/Thermo Fisher Scientific, Inc.) according to the manufacturer's protocol. RNA purity was assessed using the ND-1000 (Nanodrop; Thermo Fisher Scientific, Inc.). Each RNA sample had an A260:A280 ratio above 1.8 and an A260:A230 ratio above 2.0. RNA integrity was evaluated using the Agilent 2200 TapeStation (Agilent Technologies). Briefly, rRNAs were removed from total RNA using the EpicenterRibo-Zero rRNA Removal Kit (Illumina, Inc.) and fragmented to approximately $200 \mathrm{bp}$. Subsequently, the purified RNAs were subjected to first-strand and second-strand cDNA synthesis followed by adaptor ligation and enrichment with a low-cycle according to the instructions of the NEBNext ${ }^{\circledR}$ Ultra $^{\mathrm{TM}}$ RNA Library Prep Kit for Illumina [New England BioLabs, Inc. (NEB)]. The purified library products were evaluated using the Agilent 2200 TapeStation and Qubit ${ }^{\circledR} 2.0$ (Thermo Fisher Scientific, Inc.) and then diluted to $10 \mathrm{pM}$ for cluster generation in situ on the pair-end flow cell followed by sequencing (2x150 bp) HiSeq 3000 system (Illumina, Inc.). Clean reads were obtained after removal of reads containing adapter, poly-N and at low quality from raw data. Differential expression was assessed by DESeq using read counts as input. The Benjamini-Hochberg multiple test correction method was enabled. Differentially expressed genes were chosen according to the criteria of fold change $>2$ and adjusted P-value $<0.05$. All of the differentially expressed genes were used for heat map analysis.

Grouping of nude mice. Sixteen BALB/c nude mice (6 weeks, $\sim 18 \mathrm{~g}$, random sex) were obtained from the Experimental Animal Center of Southern China Medical University and used for tumor formation experiments. After MG63 cells were digested, they were washed twice with PBS to remove the residual medium. A total of $1 \times 10^{6}$ cells were injected into the right forelegs of the nude mice subcutaneously. The status of nude mice and tumor growth were observed every week. When the transplanted tumor reached $60-80 \mathrm{~mm}^{3}$, the nude mice were randomly divided into 4 groups: i) negative controls [intraperitoneal (i.p.) injection of normal saline, once every day); ii) DDP group (peritoneal injection of cisplatin $5 \mathrm{mg} / \mathrm{kg}$, once every other day); iii) cadmium chloride $\left(\mathrm{CdCl}_{2}\right)$ (i.p. injection of cadmium chloride $1 \mathrm{mg} / \mathrm{kg}$ ), once every other day); and iv) $\mathrm{DDP}+\mathrm{CdCl}_{2}$ (cisplatin $5 \mathrm{mg} / \mathrm{kg}+$ cadmium chloride $1 \mathrm{mg} / \mathrm{kg}$, once every other day).

Treatment of nude mice. Drug administration was performed according to the above grouping. Every 2-3 nude mice were kept in a cage. The feeding conditions were as follows: room temperature was maintained at $26-28^{\circ} \mathrm{C}$, relative humidity was maintained at $40-60 \%$, and $10 \mathrm{~h}$ of light and $14 \mathrm{~h}$ of dark were kept daily. The drinking water, defecation and mental state of the nude mice were observed every day, and a vernier caliper was used to measure the longest and shortest diameters of the transplanted tumor every two days. The volume (V) of the subcutaneous transplanted tumor was calculated $\left(\mathrm{V}=\mathrm{L} \mathrm{x} \mathrm{W}^{2} \times 0.5\right)$, and the tumor growth curve was drawn. Forty-eight hours after the last dose (after 2 weeks, about $23 \mathrm{~g}$ ), mice were anesthetized by using carbon dioxide. The specific method is as follows: The nude mouse was placed in a closed chamber $(50 \times 40 \times 40 \mathrm{~cm})$, and the air in the chamber was gradually replaced by a mixture of carbon dioxide and oxygen. The flow rate of gas was $16,000 \mathrm{~cm}^{3} / \mathrm{min}$ and the ratio of carbon dioxide and oxygen was 6:4. After 20 min when the nude mice lost consciousness, the $\mathrm{CO}_{2}$ concentration was then raised to $100 \%$ for 20 min until the nude mice died. The criteria for judging the death of the nude mice were: Stopped heartbeat, dilated pupils, and halted breathing. Tumor tissue was then removed, weighed and imaged. At the same time, blood was collected from the posterior orbital venous plexus of the nude mice, and blood routine and liver and kidney functions were measured. Automatic blood cell analyzer (ProCyte Dx; IDEXX, Inc.) was used to detect the following indicators: white blood cells (WBCs), red blood cells (RBCs), platelets (PLTs) and lymphocytes (LYMs). An automatic biochemical analyzer (Catalyst One; IDEXX, Inc.) was used to detect the following indicators: Aspartate aminotransferase (AST), alanine aminotransferase (ALT), alkaline phosphatase (ALP), uric acid (UA), urea nitrogen (BUN), and creatinine (CR). The animal experiment was performed in strict accordance with the National Institutes of Health Guide for the Care and Use of Laboratory Animals. The animal study complied with the ARRIVE guidelines and the AVMA euthanasia guidelines from $2013(14,15)$. All protocols described in this study were reviewed and approved by the Ethics Committee of the Affiliated Yuebei People's Hospital of Shantou University Medical College (Shaoguan, Guangdong, China).

Statistical analysis. All data were analyzed using SPSS 17.0 software (SPSS, Inc.). Qualitative variables are expressed as counts (\%), and quantitative variables are expressed as the mean \pm standard deviation. Measurement data that conformed to the normal distribution were analyzed using independent sample t-test and the Mann-Whitney rank sum tests were used to analyze those that did not conform to a normal distribution, while for multiple specimens, statistical analysis was performed using one-way ANOVA and a post hoc test was performed after pairwise comparison test. On the premise 
A

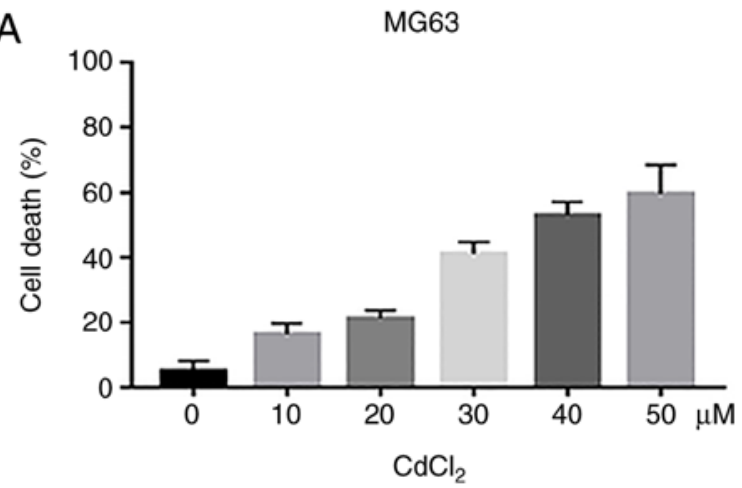

C

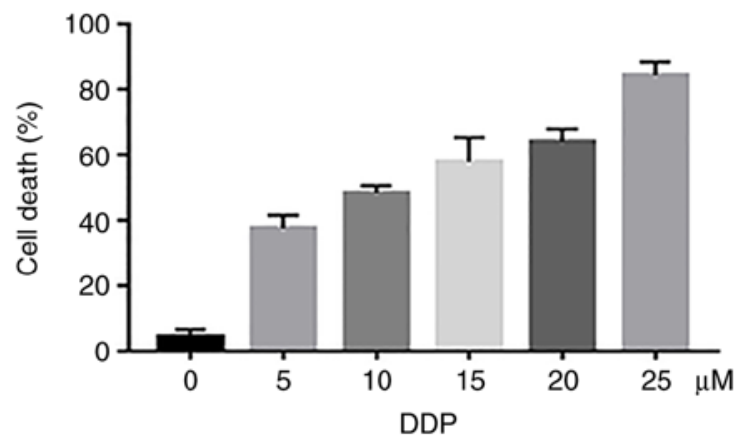

$\mathrm{E}$

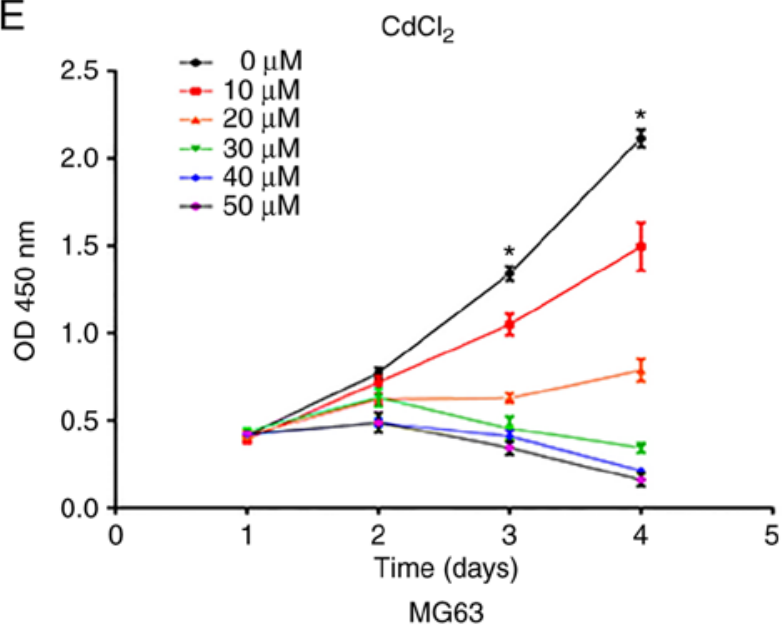

B

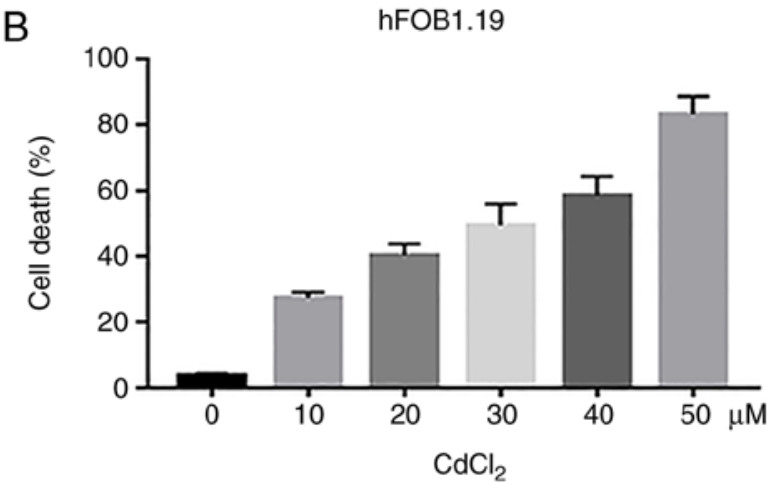

$\mathrm{D}$

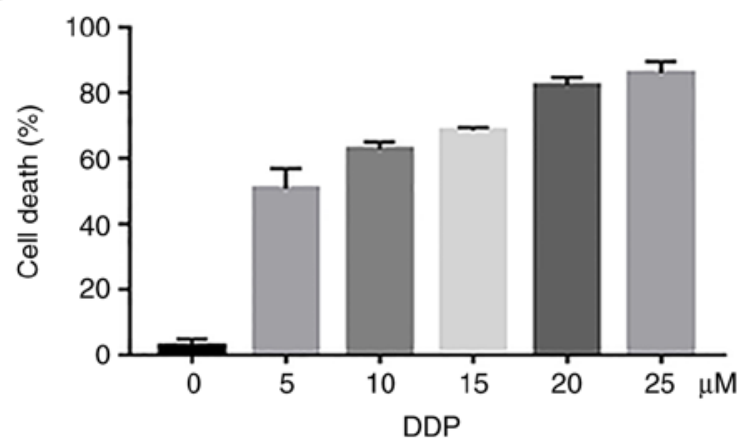

$\mathrm{F}$

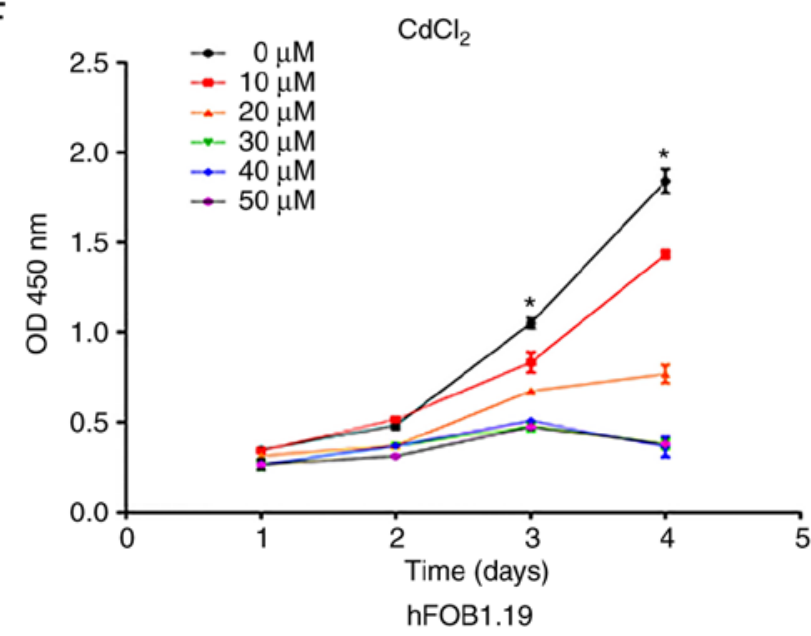

Figure 1. Cytotoxic effects of cadmium chloride $\left(\mathrm{CdCl}_{2}\right)$ and cisplatin (DDP) in osteosarcoma and osteoblast cells. (A-D) MG63 and hFOB1.19 cell death was measured by MTT assay using different concentrations $(0-50 \mu \mathrm{M})$ of $\mathrm{CdCl}_{2}$ and DDP $(0-25 \mu \mathrm{M})$. (E and F) Cell proliferation of MG63 cells and hFOB1.19 cells treated with different concentrations $(0-50 \mu \mathrm{M})$ of $\mathrm{CdCl}_{2}$ was measured by $\mathrm{MTT}$ assay. $\mathrm{P}<0.05$ compared with the control $(0 \mu \mathrm{M})$ group.

of homogeneity of variance, the post hoc test was performed by Scheffe and Tukey method. Differences were statistically significant at the $\mathrm{P}<0.05$ level.

\section{Results}

Assessment of the cytotoxicity of both cadmium chloride and DDP in osteosarcoma and normal cells. To evaluate the cytotoxicity of both cadmium chloride $\left(\mathrm{CdCl}_{2}\right)$ and DDP in OS and normal cells, we first investigated the effects of $\mathrm{CdCl}_{2}$ and DDP on MG63 human OS cells and hFOB1.19 human osteoblasts. MTT assays revealed that the cell death increased in a concentration-dependent manner (Fig. 1A-D). Compared to $\mathrm{CdCl}_{2}$, DDP was more cytotoxic. Normal cells were more sensitive to the drugs than tumor cells. The half maximal inhibitory concentration $\left(\mathrm{IC}_{50}\right)$ values of $\mathrm{CdCl}_{2}$ and DDP on MG63 cells were calculated to be $39.95 \pm 1.99$ and $12.79 \pm 0.07 \mu \mathrm{M}$, respectively. To compare the effects of different concentrations of $\mathrm{CdCl}_{2}$ on cell proliferation, MTT assays were performed. The results demonstrated that $\mathrm{CdCl}_{2}$ at a concentration of $10 \mu \mathrm{M}$ slightly inhibited cell proliferation, and when the concentration was greater than $20 \mu \mathrm{M}$, cell proliferation was significantly inhibited at day 3 and 4 compared with the untreated cells (Fig. 1E and F). The concentration of $20 \mu \mathrm{M}$ of $\mathrm{CdCl}_{2}$ was selected for subsequent experiments.

Investigation of the mechanism(s) of $\mathrm{CdCl}_{2}$ cytotoxicity. OS MG63 cells were treated with $20 \mu \mathrm{M} \mathrm{CdCl}$ for $24 \mathrm{~h}$, and 
A

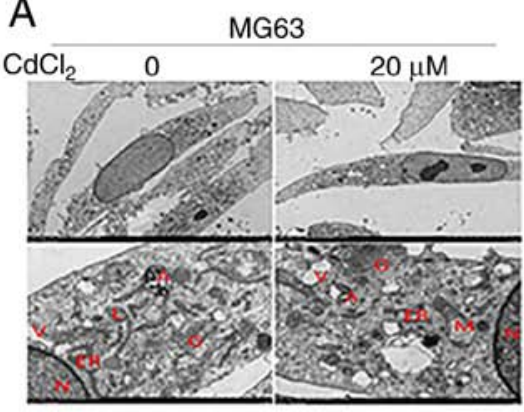

D

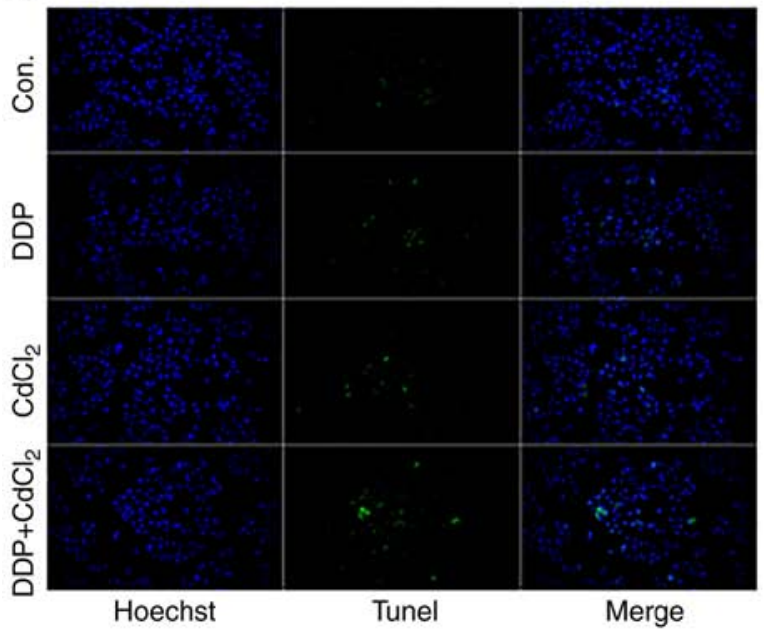

G
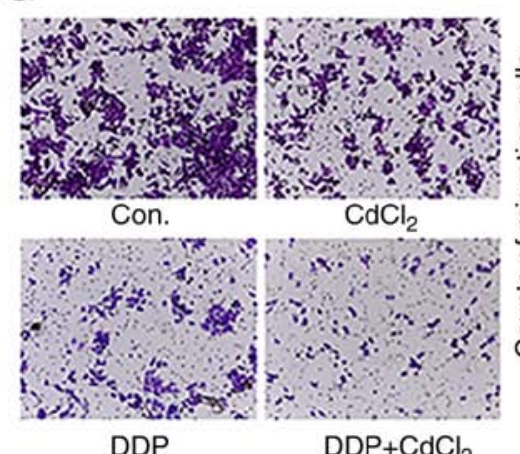

DDP

$\mathrm{H}$
B

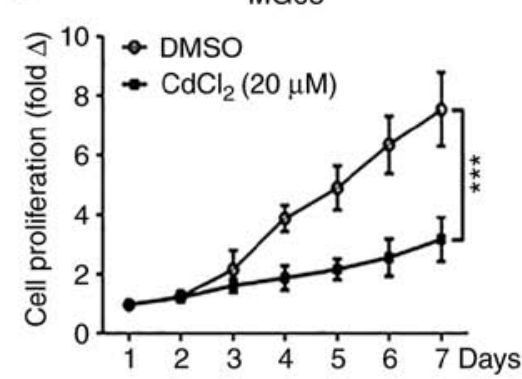

C

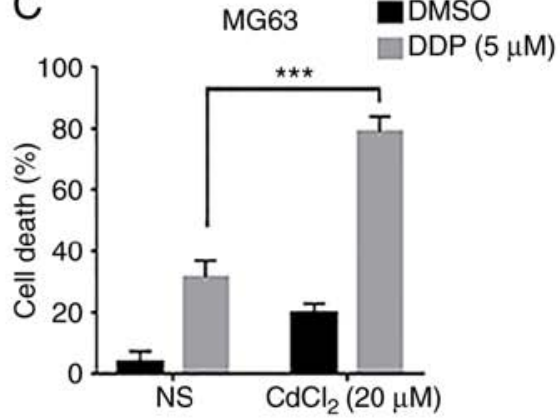

E

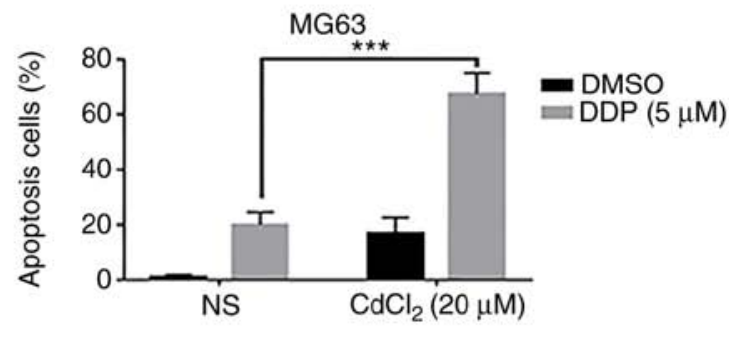

F

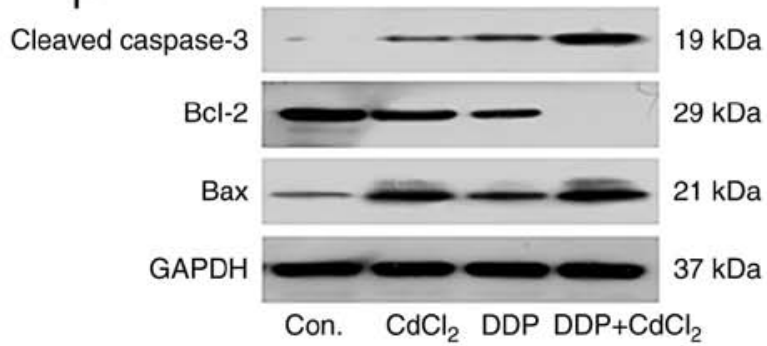

I

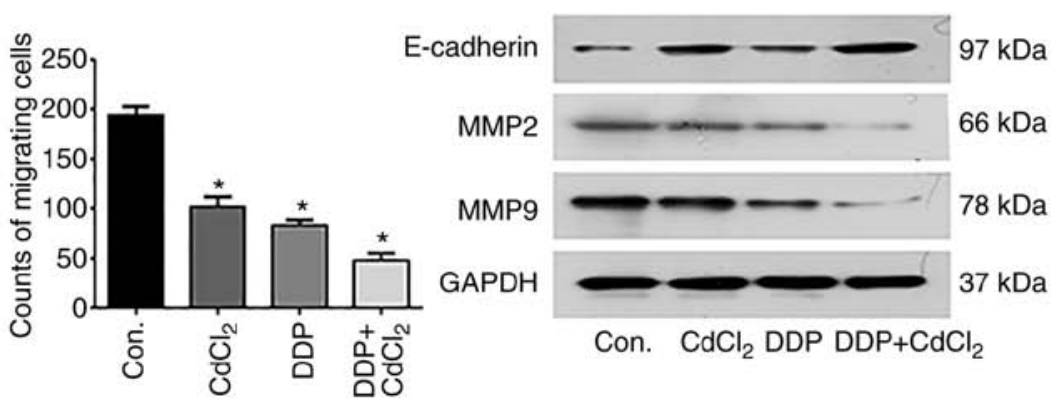

Figure 2. Effects of cadmium chloride $\left(\mathrm{CdCl}_{2}\right)$ on the survival of osteosarcoma (OS) cells. (A) Electron microscopy images of OS MG63 cells treated with $\mathrm{CdCl}_{2}$. N, M, V, A, L, ER and G indicate the nucleus, mitochondria, vacuole, autophagosome, lysosome, endoplasmic reticulum and Golgi respectively. (B) MTT results showing the cell proliferation level over 4 consecutive days in each group. (C-E) TUNEL results show the cell death and apoptosis of MG63 cells treated with DDP and/or $\mathrm{CdCl}_{2} \cdot{ }^{* * * *} \mathrm{P}<0.001$. (F) Western blot results indicate that $\mathrm{CdCl}_{2}$ promotes apoptosis in $\mathrm{MG} 63$ cells. $(\mathrm{G}$ and $\mathrm{H}$ ) The migration capacity of $\mathrm{MG} 63$ cells treated with DDP and/or $\mathrm{CdCl}_{2}$ was analyzed by Transwell assays. (I) Western blot results indicate that CdCl ${ }_{2}$ inhibits migration in MG63 cells. ${ }^{*} \mathrm{P}<0.05$, compared with the control (cont.) group.

apoptosis was assessed by electron microscopy. After treatment with $\mathrm{CdCl}_{2}$, the characteristic morphological changes of apoptosis were observed which included: Shrinkage of cell membranes, concentrated chromatin and organelles, folding of endoplasmic reticulum and appearance of apoptotic bodies outside the membrane (Fig. 2A). MTT assay results showed that compared with the control (DMSO) group, cell proliferation was significantly decreased after treatment with $\mathrm{CdCl}_{2}$ for 7 days (Fig. 2B). Meanwhile, cell apoptosis was significantly increased after treatment with DDP or $\mathrm{CdCl}_{2}$ compared with the control group, and the combined use of DDP and $\mathrm{CdCl}_{2}$ further promoted cell apoptosis (Fig. 2C-E). Western blot analysis confirmed these effects, as DDP+CdCl $\mathrm{Cl}_{2}$ treatment led to a loss of $\mathrm{Bcl}-2$ expression and increased Bax and cleaved caspase-3 levels (Fig. 2F). Then, Transwell assays were performed to investigate the cell migration level. The results revealed that $\mathrm{DDP}+\mathrm{CdCl}_{2}$ treatment significantly inhibited MG63 cell migration ability compared with the use of DDP or $\mathrm{CdCl}_{2}$ only, or the control group (Fig. $2 \mathrm{G}$ and $\mathrm{H}$ ). Western blot results confirmed that the expression of MMP2 and MMP9 was significantly inhibited while E-cadherin was increased in the $\mathrm{DDP}+\mathrm{CdCl}_{2}$ treatment group compared with the use of DDP or $\mathrm{CdCl}_{2}$ only, or the control group (Fig. 2I). This implies that DDP and $\mathrm{CdCl}_{2}$ may downregulate the migration of MG63 through the Wnt pathway. 


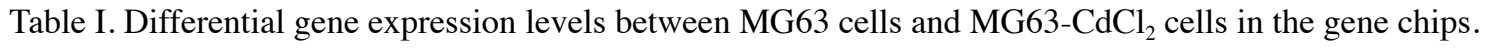

\begin{tabular}{llcrrrr}
\hline Gene & \multicolumn{1}{c}{ Gene_type } & MG63-ceM & MG63-CdCl -ceM & $\log 2(\mathrm{FC})$ & P-value & q-value \\
\hline ISG15 & Protein_coding & 454.746 & 250.452 & -0.861 & $<0.001$ & $<0.001$ \\
IFITM1 & Protein_coding & 196.566 & 87.550 & -1.167 & $<0.001$ & $<0.001$ \\
OASL & Protein_coding & 164.334 & 88.149 & -0.899 & $<0.001$ & $<0.001$ \\
IFI6 & Protein_coding & 122.105 & 68.162 & -0.841 & $<0.001$ \\
LOC728688 & Pseudogene & 96.470 & 38.221 & -1.336 & $<0.001$ & $<0.007$ \\
COL6A3 & Protein_coding & 726.174 & 453.297 & -0.680 & $<0.001$ & $<0.001$ \\
NDRG1 & Protein_coding & 428.946 & 281.864 & -0.606 & $<0.001$ & $<0.001$ \\
RPPH1 & RNase_P_RNA & 92.824 & 22.347 & -2.054 & $<0.001$ & $<0.001$ \\
RN7SK & SnRNA & 298.014 & 100.370 & -1.570 & $<0.001$ & $<0.001$ \\
RMRP & RNase_MRP_RNA & 253.020 & 74.464 & -1.765 & $<0.001$ & $<0.001$ \\
FOXM1 & Protein_coding & 121.922 & 66.312 & -0.879 & $<0.001$ & 0.004 \\
\end{tabular}

MG63-ceM, average expression value of each gene in MG63 cells; $\mathrm{MG}_{3}-\mathrm{CdCl}_{2}$-ceM, average expression value of each gene in $\mathrm{MG}$-CdCl cells; $\log 2$ (FC), fold change in expression after $\log 2$ transformation; P-value, significance of the correlation analysis; $q$ value, $\mathrm{P}$-value correction. FOXM1, forkhead box protein M1.

Investigation of the mechanism(s) by which cadmium chloride inhibits $O S$. To investigate the mechanism(s) by which $\mathrm{CdCl}_{2}$ inhibits $\mathrm{OS}$, we performed gene chip screening of $\mathrm{CdCl}_{2}$-treated MG63 cells and the untreated cells. Heatmaps were constructed based on the differentially expressed genes between the treatment groups (Fig. 3A, Table I), of which FOXM1 was identified as being significantly downregulated in response to treatment with $\mathrm{CdCl}_{2}$. To investigate the effects of FOXM1 on OS cells, Western blotting was adopted to explore the expression of FOXM1 in OS cell lines. The results demonstrated that the expression of FOXM1 in MG63, U2OS, 143B and SaoS2 OS cells was higher than that in the hFOB.19 cells (Fig. 3B). Then, FOXM1-overexpressing and -silenced lentiviruses were constructed. Results of the Western blot analysis and qRT-PCR showed that the expression of FOXM1 in the sh-FOXM1 and the FOXM1 group were significantly lower and higher, respectively, than that in the control (shNC and Vector) groups (Fig. 3C and D). In the FOXM1-silenced (sh-FOXM1) cells, low concentrations of DDP significantly reduced OS cell viability (Fig. 3E). Conversely, high DPP concentrations were required to reduce the viability of FOXM1-overexpressing (FOXM1) cells when compared to the Vector group (Fig. 3F), thus confirming a role for FOXM1 in DPP-mediated cell death. DPP treatment of FOXM1-silenced MG63 cells induced cell apoptosis, while DPP treatment of FOXM1-overexpressing MG63 cells inhibited cell apoptosis (Fig. 3G and $\mathrm{H}$ ). These results were verified by Western blot analysis. Compared with the control group, silencing of FOXM1 upregulated the expression of cleaved caspase- 3 and Bax levels, and downregulated the expression of Bcl-2 levels. Addiitonally, overexpression of FOXM1 led to the opposite trend in regards to the expression of cleaved caspase-3, Bax and Bcl-2 levels (Fig. 3I).

Assessment of the regulatory relationship between cadmium chloride and FOXM1 in OS cells. To verify the regulatory relationship between $\mathrm{CdCl}_{2}$ and FOXM1 in OS cells, MG63 cells were treated with various concentrations of $\mathrm{CdCl}_{2}$, and the expression of FOXM1 was verified by qPCR and Western blot analysis. FOXM1 levels were decreased with increasing $\mathrm{CdCl}_{2}$ concentrations at both the mRNA and protein levels (Fig. 4A and B). We next investigated the effects of FOXM1 expression on the response of OS cells to $\mathrm{DDP}+\mathrm{CdCl}_{2}$ treatment. qPCR and Western blotting results demonstrated that after MG63 cells were treated with DPP, FOXM1 expression was upregulated, and the combined use of DDP+CdCl significantly suppressed the expression of FOXM1 in MG63 cells compared to the control cells (Fig. 4C and D). In FOXM1-silenced MG63 cells, MTT results showed that DDP led to an increase in the MG63 cell death rate compared to the shNC cells. DDP+CdCl${ }_{2}$ treatment of the sh-FOXM1 cells yielded no significant change in cell death. Meanwhile, $\mathrm{DDP}+\mathrm{CdCl}_{2}$ treatment of the shNC cells resulted in higher apoptosis compared with the DDP alone treated cells (Fig. 4E).

In vivo nude mouse OS model. To confirm these findings in vivo, nude mice were implanted with OS MG63 cells (Fig. 5A), and the effects of DDP $+\mathrm{CdCl}_{2}$ combination therapy were assessed after 14 days of treatment in the i) control (Con.), ii) DDP, iii $\mathrm{CdCl}_{2}$ and iv) $\mathrm{DDP}+\mathrm{CdCl}_{2}$ groups. We first tested the safety of the $\mathrm{DDP}+\mathrm{CdCl}_{2}$ combination. $\mathrm{DDP}+\mathrm{CdCl}_{2}$ caused changes in blood routine and liver and kidney function in nude mice (Tables II and III). The results showed that $\mathrm{DDP}+\mathrm{CdCl}_{2}$ increased WBCs, PLTs, LYMs, ALT, ALP, UA, BUN, and CR levels compared with control group in venous blood. There was no significant effect on red RBCs or AST levels. Then, we measured the tumor volumes and weight (Fig. 5B and C). Compared with the control group and the use of DDP or $\mathrm{CdCl}_{2}$ group, treatment with $\mathrm{DDP}+\mathrm{CdCl}_{2}$ reduced tumor volume and weight, and $\mathrm{DDP}+\mathrm{CdCl}_{2}$ had the most significant effect compared with the use of DDP or $\mathrm{CdCl}_{2}$ alone. Tumor tissues were isolated, and FOXM1 expression was assessed by immunohistochemical (IHC) staining (Fig. 5D), Western blot analysis (Fig. 5E) and qPCR (Fig. 5F). Similar to the results of the in vitro experiments, DDP upregulated FOXM1 expression while $\mathrm{CdCl}_{2}$ inhibited FOXM1 expression. 

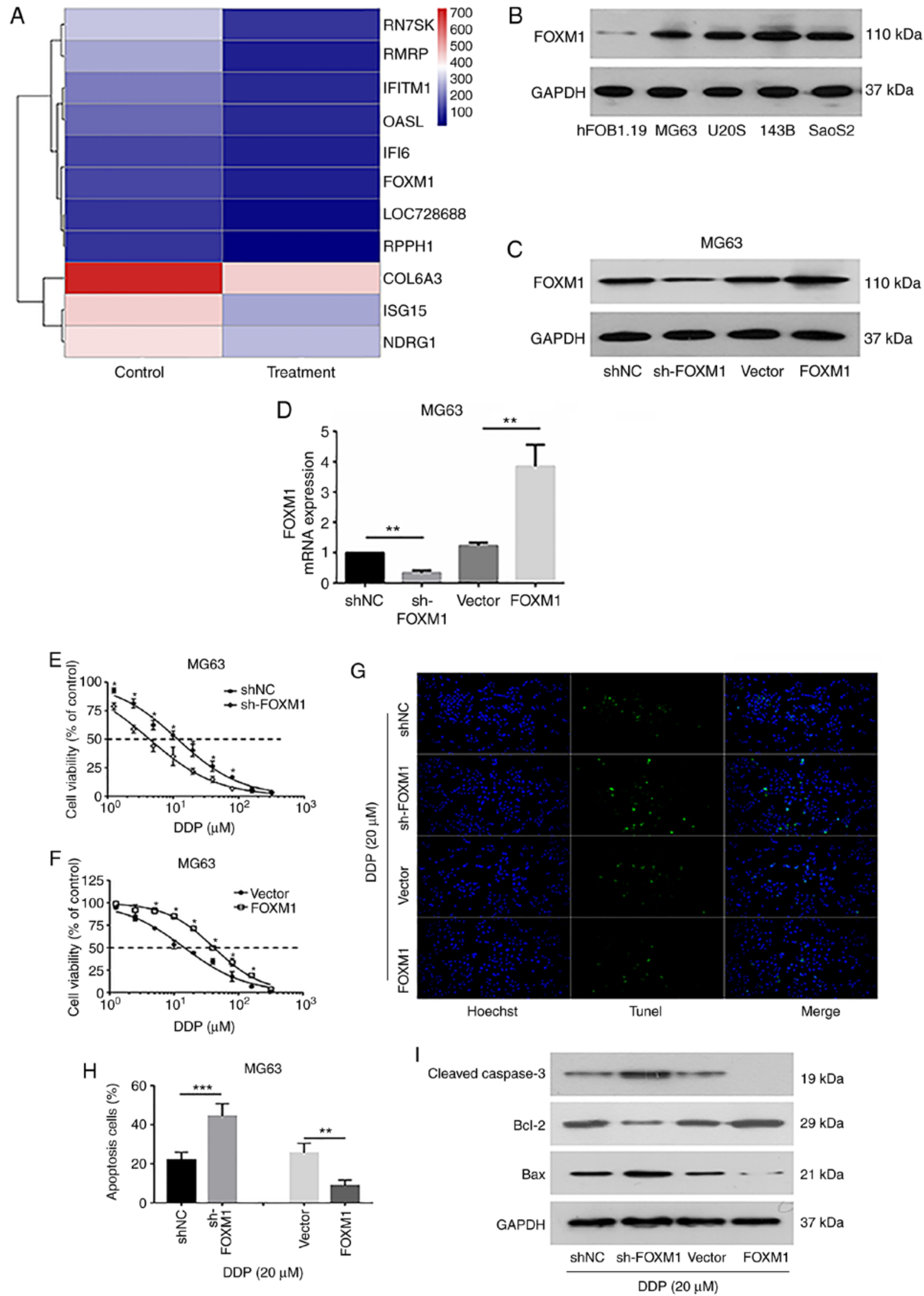

Figure 3. Effects of cadmium chloride $\left(\mathrm{CdCl}_{2}\right)$ on c expression in the osteosarcoma (OS) cells. (A) Heatmap results show differential expression after MG63 cells were treated with $\mathrm{CdCl}_{2}$. (B) Western blotting results showed high FOXM1 expression in human OS cell lines. (C and D) Western blotting and qPCR were used to measure FOXM1 protein and mRNA expression in MG63 cells following transfection and silencing of FOXM1. (E and F) Detection of viability of MG63 cells following silencing (sh-FOXM1) or overexpression of FOXM1 lentivirus as compared with the shNC and vector groups by MTT assay. Apoptosis in MG63 cells was assessed using (G and H) TUNEL assays and (I) Western blotting $48 \mathrm{~h}$ after FOXM1 transfection. ${ }^{*} \mathrm{P}<0.05,{ }^{* *} \mathrm{P}<0.01,{ }^{*{ }^{* * *}} \mathrm{P}<0.001$, compared with the respective shNC and Vector group. 

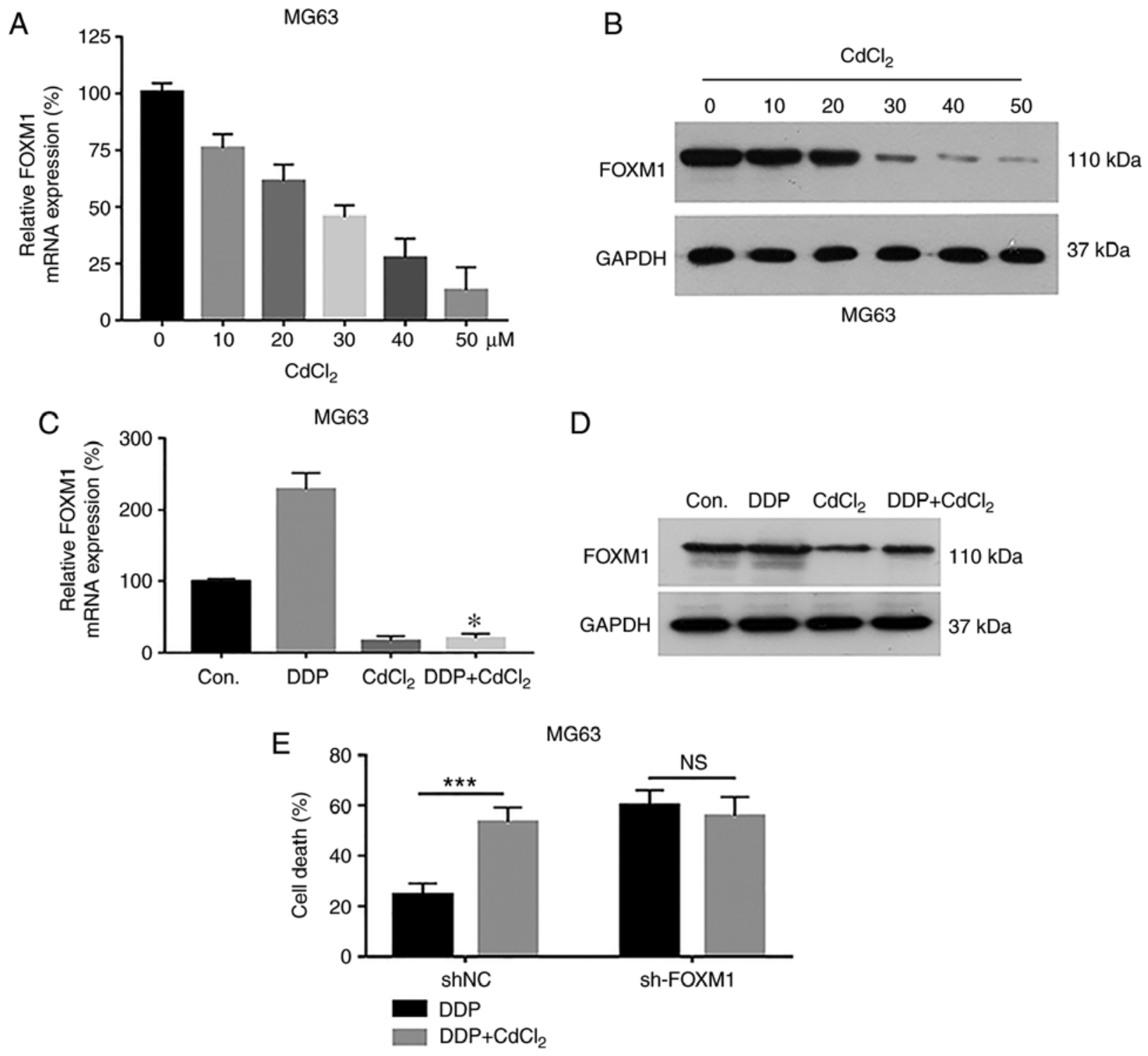

Figure 4. Effects of forkhead box protein M1 (FOXM1) expression on cadmium chloride $\left(\mathrm{CdCl}_{2}\right)+$ DDP-mediated MG63 cell death. (A) qPCR and (B) Western blot analysis of FOXM1 in MG63 cells treated with different concentrations $(0-50 \mu \mathrm{M})$ of $\mathrm{CdCl}_{2}$. (C) qPCR and (D) Western blot analysis results showed that $\mathrm{CdCl}_{2}$ and/or DDP treatment inhibited FOXM1 protein expression in the $\mathrm{MG}_{3}$ cells. (E) Detection of cell death in response to DDP and/or CdCl ${ }_{2}$ in MG63 cells after silencing of FOXM1 by MTT assay. ${ }^{*} \mathrm{P}<0.05$, compared with the control (cont.) group. ${ }^{* * *} \mathrm{P}<0.001$; NS, not significant.

\section{Discussion}

Osteosarcoma (OS) is a common malignant tumor in childhood and adolescence, with an global annual incidence of $\sim 3.1$ million for the past 20 years $(16,17)$. OS occurs in the metaphyseal end of adolescent long tubular bones and shows early blood metastasis and rapid progression. Current therapies include neoadjuvant chemotherapy combined with limb salvage, but specific treatments are lacking. Although this approach preserves joint function in the limbs, metastasis and OS recurrence are frequent. Surgery is also challenging and requires tumor resection and limb reconstruction (3). Chemotherapy resistance presents an additional challenge. Although next-generation sequencing to explore drug resistance genes in patients with OS has been proposed with the ultimate aim of precision therapy, this approach is limited by the high mutational rates associated with OS (18-20). Further studies to explore OS pathogenesis and new therapeutic targets are urgently required.
Commonly used chemotherapy drugs include adriamycin, cisplatin and methotrexate. Other less frequently used drugs include ifosfamide and vincristine. DDP is commonly used for OS but its therapeutic effect has not improved over the last 30 years, primarily due to drug-resistance $(2,21)$. As a classic chemotherapy drug, cisplatin binds DNA after entering tumor cells, forming intrachain and interchain adducts destroying the normal DNA structure, promoting DNA damage, inhibiting DNA replication and transcription, and enhancing tumor cell death. In resistant cells, cisplatin accumulation is reduced (22) and the DNA damage responses of tumor cells are enhanced (23). These cells are also resistant to autophagy (24), an important cause of OS tolerance to cisplatin. Overcoming the tolerance of OS to cisplatin can increase its sensitivity during clinical treatment (25). We therefore explored whether short-term cadmium chloride treatment can enhance the sensitivity of OS to cisplatin to improve its efficacy. 
A

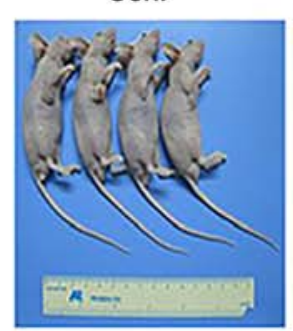

DDP

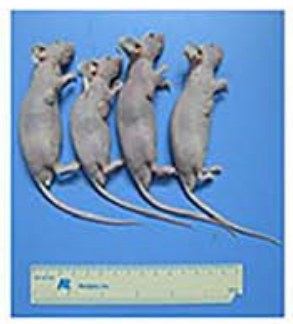

$\mathrm{CdCl}_{2}$

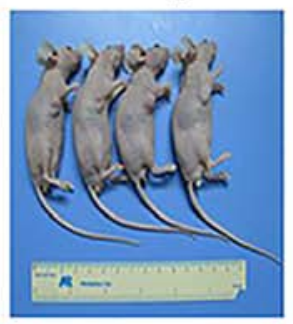

$\mathrm{DDP}+\mathrm{CdCl}_{2}$

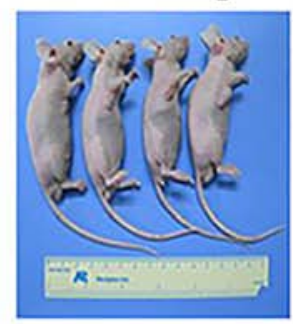

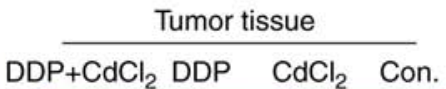

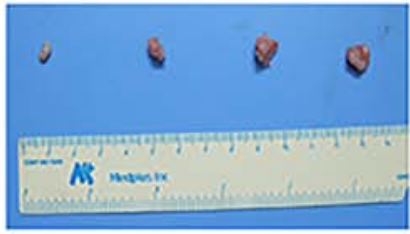

B

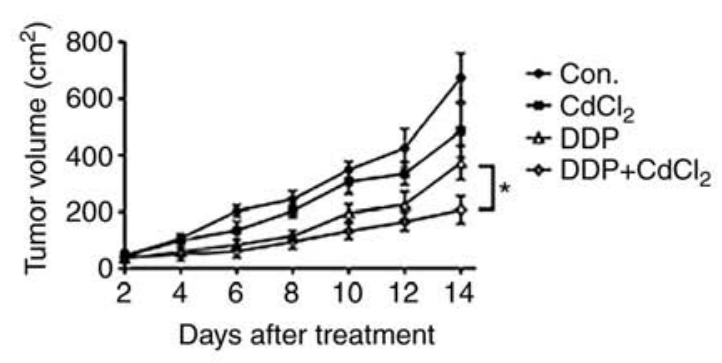

D

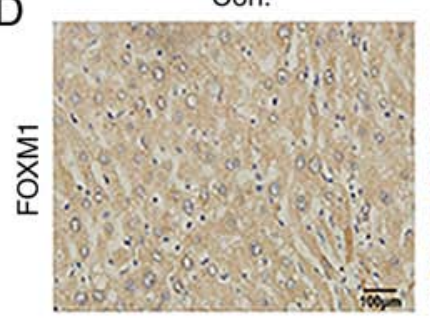

E

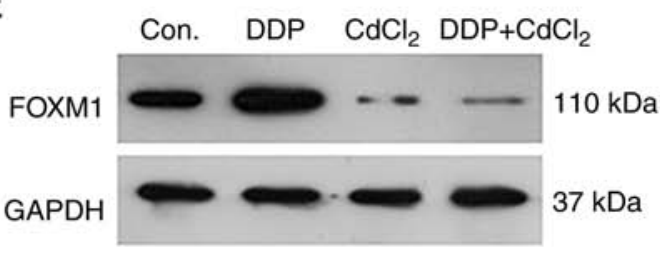

C

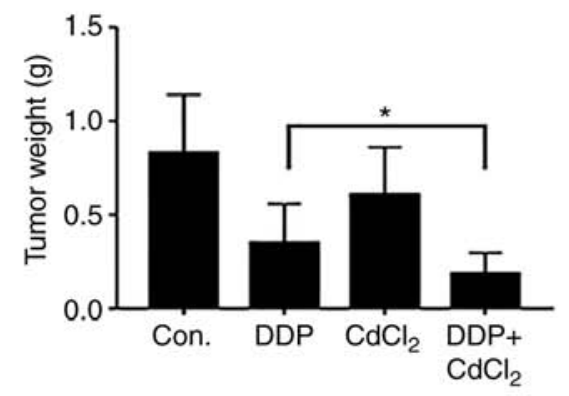

Con.
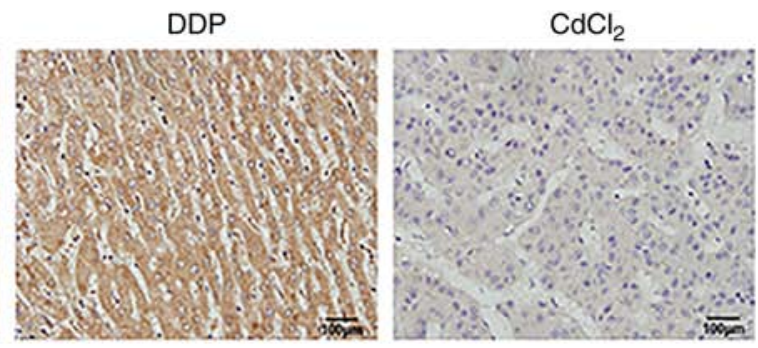

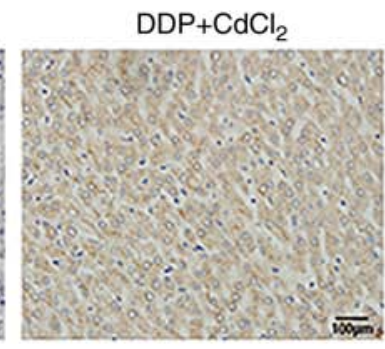

Tumor

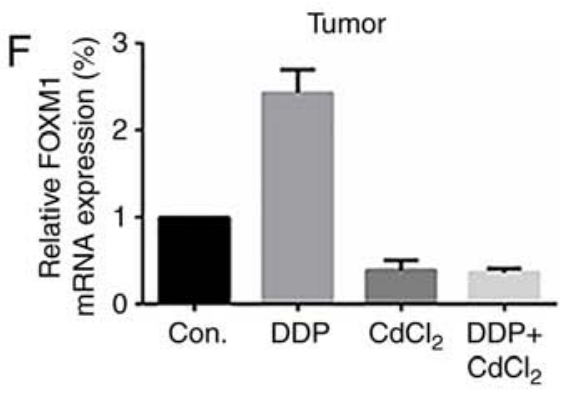

Figure 5. Effects of cadmium chloride $\left(\mathrm{CdCl}_{2}\right)$ in combination with DDP on tumor formation in nude mice. (A) General images of nude mouse tumors after the different treatments. (B) Tumor volume and (C) tumor weight were measured after different treatments. (D) FOXM1 protein levels in the IHC analysis of nude mouse tumors after different treatments. (E) Western blot analysis and (F) qPCR analysis of FOXM1 in nude mouse tumors after different treatments. ${ }^{*} \mathrm{P}<0.05$.

Previous studies have shown that forkhead box protein M1 (FOXM1) regulates cell proliferation, and its expression varies according to the cell cycle status. FOXM1 levels are low in G0, gradually increase in G1, peak in late G1 and early S, and remain high during $M$ phase. When cells enter the $M$ phase, FOXM1 is rapidly degraded, and its expression sharply declines. FOXM1 regulates cell cycle progression through its role in DNA repair, chromatin assembly, and maintenance of chromosomal stability to ensure that mitosis proceeds and that cell proliferation occurs $(26,27)$. FOXM1 is highly expressed in a variety of solid tumor tissues, and its inhibition prevents tumor proliferation and apoptosis $(28,29)$. In addition, FOXM1 is highly expressed in proliferating cells, where it regulates DNA damage repair, tissue homeostasis and chemoresistance (30). FOXM1 promotes tumor cell survival in hypoxic environments, and the loss of FOXM1 expression impairs the proliferation of hypoxic tumor cells (23). FOXM1 also induces breast cancer cell resistance to epirubicin by upregulating MRN complexes $(31,32)$.

In the present study, cadmium chloride was found to induce MG63 cell apoptosis, inhibit MG63 cell proliferation and migration, and enhance the regulatory effect of cisplatin (DDP) in OS MG63 cells. Wnt signaling pathway is widely involved in the regulation of cell proliferation, survival, apoptosis, migration and metastasis $(33,34)$. We further found that chromium chloride can activate the Wnt signaling pathway and the Bcl-2 protein family. Therefore, the regulation of chromium chloride on MG63 cells may be related to the activation of Wnt signaling pathway. Cadmium chloride was also found to increase the sensitivity of OS cells to cisplatin in vitro and in vivo. OS cells treated with cadmium chloride were screened through gene chip assays in which the expression of FOXM1 was found to be significantly decreased. FOXM1 silencing enhanced the effects of DDP and cadmium chloride on 
Table II. Analysis of routine blood indicators of the mice in each group.

\begin{tabular}{|c|c|c|c|c|c|}
\hline \multirow[b]{2}{*}{ Index } & \multicolumn{5}{|c|}{ Treatment group } \\
\hline & Con. & $\mathrm{CdCl}_{2}$ & DDP & $\mathrm{DDP}+\mathrm{CdCl}_{2}$ & P-value \\
\hline $\mathrm{WBCs}^{\mathrm{a}}$ & $2.528 \pm 0.057$ & $2.618 \pm 0.120$ & $2.743 \pm 0.185$ & $2.848 \pm 0.174$ & 0.005 \\
\hline $\mathrm{RBCs}^{\mathrm{b}}$ & $8.918 \pm 0.036$ & $8.833 \pm 0.079$ & $8.893 \pm 0.073$ & $8.858 \pm 0.059$ & 0.116 \\
\hline PLTs $^{\mathrm{a}}$ & $693.29 \pm 2.614$ & $725.72 \pm 53.35$ & $772.38 \pm 64.68$ & $840.57 \pm 90.46$ & 0.003 \\
\hline LYMs $^{\mathrm{a}}$ & $2.123 \pm 0.082$ & $2.153 \pm 0.067$ & $2.440 \pm 0.346$ & $2.660 \pm 0.102$ & 0.001 \\
\hline
\end{tabular}

${ }^{a}$ Unit is expressed as $1 \times 10^{9} / 1$; ${ }^{b}$ unit is expressed as $1 \times 10^{12} / 1$. WBCs, white blood cells; RBCs, red blood cells; PLTs, platelets; LYMs, lymphocytes. Con., control; $\mathrm{CdCl}_{2}$, cadmium chloride; DDP, cisplatin.

Table III. Analysis of the biochemical blood indices of the mice in each group.

\begin{tabular}{lcrrr}
\hline & \multicolumn{3}{c}{ Treatment group } \\
\cline { 2 - 5 } Index & \multicolumn{1}{c}{ Con. } & \multicolumn{1}{c}{$\mathrm{CdCl}_{2}$} & DDP & $\mathrm{DDP}^{2} \mathrm{CdCl}_{2}$ \\
\hline $\mathrm{AST}^{\mathrm{a}}$ & $127.13 \pm 2.09$ & $127.23 \pm 3.20$ & $128.00 \pm 3.36$ & $124.70 \pm 2.51$ \\
$\mathrm{ALT}^{\mathrm{a}}$ & $44.35 \pm 0.48$ & $44.80 \pm 0.71$ & $49.33 \pm 0.97$ & $56.18 \pm 2.16$ \\
$\mathrm{ALP}^{\mathrm{a}}$ & $363.8 \pm 11.65$ & $367.9 \pm 14.76$ & $343.0 \pm 17.2$ & $366.8 \pm 17.6$ \\
$\mathrm{UA}^{\mathrm{b}}$ & $143.80 \pm 0.91$ & $148.4 \pm 2.30$ & $159.63 \pm 1.63$ & $162.20 \pm 2.51$ \\
$\mathrm{BUN}^{\mathrm{c}}$ & $7.49 \pm 0.07$ & $7.66 \pm 0.05$ & $8.24 \pm 0.25$ & 0.001 \\
$\mathrm{CR}^{\mathrm{b}}$ & $105.20 \pm 1.54$ & $104.32 \pm 2.06$ & $127.03 \pm 1.02$ & 0.031 \\
\hline
\end{tabular}

${ }^{a}$ Unit is expressed in $\mathrm{U} / 1$; ${ }^{\mathrm{b}}$ unit is expressed in $\mu \mathrm{mol} / \mathrm{l}$; ${ }^{\mathrm{c}}$ unit is expressed in $\mathrm{mmol} / \mathrm{l}$. AST, aspartate aminotransferase; ALT, alanine aminotransferase; ALP, alkaline phosphatase; UA, uric acid; BUN, urea nitrogen; $\mathrm{CR}$, creatinine. Con., control; $\mathrm{CdCl}_{2}$, cadmium chloride; DDP, cisplatin.

growth inhibition and apoptosis, while FOXM1 overexpression increased cell survival. These findings were confirmed in in vivo models, in which mice treated with DDP and/or cadmium chloride showed reduced OS tumor growth. IHC staining confirmed altered FOXM1 expression in tumor cells treated with cadmium chloride alone or in combination with DPP, confirming its role in DPP resistance. This highlighted the ability of cadmium chloride to improve the therapeutic effects of DPP.

The use of cadmium chloride in combination with DPP as a treatment for OS poses challenges. First, cadmium chloride enhances DPP sensitization, but its optimal concentrations for use are unknown. Second, the effects of cadmium chloride on tissue toxicity and immune responses must be assessed. In addition, the pharmacokinetics of cadmium chloride in vivo require assessment to confirm its absorption, distribution and metabolic elimination.

Taken together, this study demonstrated that exogenous cadmium chloride reduces the expression of the resistance gene FOXM1 in OS cells and enhances the therapeutic effects of DPP on OS. This highlights cadmium chloride as a therapeutic adjuvant to reduce cisplatin-induced drug resistance.

\section{Acknowledgements}

Not applicable.

\section{Funding}

The present study was supported in part by a grant from the Guangdong Provincial Science and Technology Project (2017A020215080).

\section{Availability of data and materials}

The datasets used during the present study are available from the corresponding author upon reasonable request.

\section{Authors' contributions}

YD and $\mathrm{KH}$ conceived and designed the study. KH, WX and WQ performed the experiments. KH, SN, SY and GT analyzed the data and wrote the manuscript. KH, WQ and YD reviewed the data and edited the manuscript. All authors read and approved the manuscript and agree to be accountable for all aspects of the research in ensuring that the accuracy or integrity of any part of the work are appropriately investigated and resolved.

\section{Ethics approval and consent to participate}

The animal experiment was performed in strict accordance with the National Institutes of Health Guide for the Care and 
Use of Laboratory Animals. The animal study complied with the ARRIVE guidelines and the AVMA euthanasia guidelines from 2013. All protocols described in this study were reviewed and approved by the Ethics Committee of the Affiliated Yuebei People's Hospital of Shantou University Medical College (Shaoguan, Guangdong, China).

\section{Patient consent for publication}

Not applicable.

\section{Competing interests}

The authors state that they have no competing interests.

\section{References}

1. Anninga JK, Gelderblom H, Fiocco M, Kroep JR, Taminiau AH, Hogendoorn PC and Egeler RM: Chemotherapeutic adjuvant treatment for osteosarcoma: Where do we stand? Eur J Cancer 47: 2431-2445, 2011

2. Kansara M, Teng MW, Smyth MJ and Thomas DM: Translational biology of osteosarcoma. Nat Rev Cancer 14: 722-735, 2014.

3. Ritter J and Bielack SS: Osteosarcoma. Ann Oncol 21 (Suppl 7): vii320-325, 2010.

4. Ferrari S and Serra M: An update on chemotherapy for osteosarcoma. Expert Opin Pharmacother 16: 2727-2736, 2015.

5. Moriarity BS, Otto GM, Rahrmann EP, Rathe SK, Wolf NK, Weg MT, Manlove LA, LaRue RS, Temiz NA, Molyneux SD, et al: A Sleeping Beauty forward genetic screen identifies new genes and pathways driving osteosarcoma development and metastasis. $\mathrm{Na}$ Genet 47: 615-624, 2015.

6. Baranski Z, Booij TH, Cleton-Jansen AM, Price LS, van de Water B, Bovée JV, Hogendoorn PC and Danen EH: Aven-mediated checkpoint kinase control regulates proliferation and resistance to chemotherapy in conventional osteosarcoma. J Pathol 236: 348-359, 2015.

7. Holmboe L, Andersen AM, Mørkrid L, Slørdal L and Hall KS High dose methotrexate chemotherapy: Pharmacokinetics, folate and toxicity in osteosarcoma patients. Br J Clin Pharmacol 73: 106-114, 2012.

8. Wallin M, Barregard L, Sallsten G, Lundh T, Karlsson MK, Lorentzon M, Ohlsson C and Mellström D: Low-level cadmium exposure is associated with decreased bone mineral density and increased risk of incident fractures in elderly men: The MrOS Sweden Study. J Bone Miner Res 31: 732-741, 2016.

9. Akesson A, Bjellerup P, Lundh T, Lidfeldt J, Nerbrand C, Samsioe G, Skerfving S and Vahter M: Cadmium-induced effects on bone in a population-based study of women. Environ Health Perspect 114: 830-834, 2006.

10. Coogan TP, Achanzar WE and Waalkes MP: Spontaneous transformation of cultured rat liver (TRL 1215) cells is associated with down-regulation of metallothionein: Implications for sensitivity to cadmium cytotoxicity and genotoxicity. J Environ Pathol Toxicol Oncol 19: 261-273, 2000.

11. Benbrahim-Tallaa L, Waterland RA, Dill AL, Webber MM and Waalkes MP: Tumor suppressor gene inactivation during cadmium-induced malignant transformation of human prostate cells correlates with overexpression of de novo DNA methyltransferase. Environ Health Perspect 115: 1454-1459, 2007.

12. Xie D and Sheng Z: Low-level cadmium exposure and bone health. J Bone Miner Res 32: 419, 2017.

13. Livak KJ and Schmittgen TD: Analysis of relative gene expression data using real-time quantitative PCR and the 2(-Delta Delta C(T)) method. Methods 25: 402-408, 2001.

14. Kahler SC: Integrating cultural competence: Animal health food safety ultimately benefit as AVMA incorporates cultura competence in CE. J Am Vet Med Assoc 242: 1186-1187, 2013.
15. Rice ASC, Morland R, Huang W, Currie GL, Sena ES and Macleod MR: Transparency in the reporting of in vivo pre-clinical pain research: The relevance and implications of the ARRIVE (Animal research: Reporting in vivo experiments) guidelines. Scand J Pain 4: 58-62, 2013.

16. Picci P: Osteosarcoma (osteogenic sarcoma). Orphanet J Rare Dis 2: 6, 2007.

17. Jaffe N: Osteosarcoma: Review of the past, impact on the future. The American experience. Cancer Treat Res 152: 239-262, 2009.

18. Do SI, Jung WW, Kim HS and Park YK: The expression of epidermal growth factor receptor and its downstream signaling molecules in osteosarcoma. Int J Oncol 34: 797-803, 2009.

19. Man TK, Lu XY, Jaeweon K, Perlaky L, Harris CP, Shah S, Ladanyi M, Gorlick R, Lau CC and Rao PH: Genome-wide array comparative genomic hybridization analysis reveals distinct amplifications in osteosarcoma. BMC Cancer 4: 45, 2004.

20. Lau CC, Harris CP, Lu XY, Perlaky L, Gogineni S, Chintagumpala M, Hicks J, Johnson ME, Davino NA, Huvos AG, et al: Frequent amplification and rearrangement of chromosomal bands 6p12-p21 and 17p11.2 in osteosarcoma. Genes, Chromos Cancer 39: 11-21, 2004.

21. Luetke A, Meyers PA, Lewis I and Juergens H: Osteosarcoma treatment-Where do we stand? A state of the art review. Cancer Treat Rev 40: 523-532, 2014.

22. Martelli L, Di Mario F, Botti P, Ragazzi E, Martelli M and Kelland L: Accumulation, platinum-DNA adduct formation and cytotoxicity of cisplatin, oxaliplatin and satraplatin in sensitive and resistant human osteosarcoma cell lines, characterized by p53 wild-type status. Biochem Pharmacol 74: 20-27, 2007.

23. Liang Q, Dexheimer TS, Zhang P, Rosenthal AS, Villamil MA, You C, Zhang Q, Chen J, Ott CA, Sun H, et al: A selective USP1-UAF1 inhibitor links deubiquitination to DNA damage responses. Nat Chem Biol 10: 298-304, 2014.

24. Levy JM, Towers CG and Thorburn A: Targeting autophagy in cancer. Nat Rev Cancer 17: 528-542, 2017.

25. Shibata A, Moiani D, Arvai AS, Perry J, Harding SM, Genois MM, Maity R, van Rossum-Fikkert S, Kertokalio A, Romoli F, et al: DNA double-strand break repair pathway choice is directed by distinct MRE11 nuclease activities. Mol Cell 53: 7-18, 2014.

26. Koo CY, Muir KW and Lam EW: FOXM1: From cancer initiation to progression and treatment. Biochim Biophys Acta 1819: 28-37, 2012.

27. Uddin S, Hussain AR, Ahmed M, Siddiqui K, Al-Dayel F, Bavi P and Al-Kuraya KS: Overexpression of FoxM1 offers a promising therapeutic target in diffuse large B-cell lymphoma. Haematologica 97: 1092-1100, 2012.

28. Wang M and Gartel AL: The suppression of FOXM1 and its targets in breast cancer xenograft tumors by siRNA. Oncotarget 2 : 1218-1226, 2011.

29. Pandit B and Gartel AL: FoxM1 knockdown sensitizes human cancer cells to proteasome inhibitor-induced apoptosis but not to autophagy. Cell Cycle 10: 3269-3273, 2011.

30. Nestal de Moraes G, Bella L, Zona S, Burton MJ and Lam EW: Insights into a critical role of the FOXO3a-FOXM1 axis in DNA damage response and genotoxic drug resistance. Curr Drug Targets 17: 164-177, 2016.

31. Peake BF, Eze SM, Yang L, Castellino RC and Nahta R: Growth differentiation factor 15 mediates epithelial mesenchymal transition and invasion of breast cancers through IGF-1R-FoxM1 signaling. Oncotarget 8: 94393-94406, 2017.

32. Khongkow P, Karunarathna U, Khongkow M, Gong C, Gomes AR, Yagüe E, Monteiro LJ, Kongsema M, Zona S, Man EP, et al: FOXM1 targets NBS1 to regulate DNA damage-induced senescence and epirubicin resistance. Oncogene 33: 4144-4155, 2014.

33. Zerlin M, Julius MA and Kitajewski J: Wnt/Frizzled signaling in angiogenesis. Angiogenesis 11: 63-69, 2008.

34. Oltvai ZN, Milliman CL and Korsmeyer SJ: Bcl-2 heterodimerizes in vivo with a conserved homolog, Bax, that accelerates programmed cell death. Cell 74: 609-619, 1993.

(i) $(5)$ This work is licensed under a Creative Commons Attribution-NonCommercial-NoDerivatives 4.0 International (CC BY-NC-ND 4.0) License. 